\title{
Pink Disease Caused by Erythricium salmonicolor (Berk. \& Broome) Burdsall: An Epidemiological Assessment of its Potential Effect on Cocoa Production in Ghana
}

\author{
Andrews Y Akrofi ${ }^{*}$, Amoako-Atta I, Assuah M and Kumi-Asare E \\ Cocoa Research Institute of Ghana, P. O. Box 8, Akim Tafo, Ghana
}

\begin{abstract}
Pink disease caused by Erythricium salmonicolor (Berk. \& Broome) Burdsall has been reported on Theobroma cacao, $\mathrm{L}$ (cacao) in Ghana for many years but has not been studied in detail. During an epidemiological assessment of the potential effect of the disease on cocoa production in the Western region of Ghana, the disease was found on 393 out of 25,600 cacao trees inspected and on 46 out of 128 farms surveyed. Typical symptoms of pink disease were observed on infected branches and four different growth forms, cobwebby, pink to salmon encrustation, creamy pustules and orange fruiting bodies were identified. Based on the symptoms in the field, microscopic examination of the fruiting bodies and pathogenicity tests, all the isolates were identified as E. salmonicolor, Berk. \& Broome. Generally, pink disease significantly $(p<0.05)$ reduced cocoa pod production but the reduction was more pronounced in the canopy ( 8.6 pods/tree) than on the trunk ( 6.7 pods/tree). Reduction in pod production also increased with increase in disease severity. Differences were observed in disease control with the different fungicides evaluated but Kocide 2000 DF proved most effective in controlling the disease. Pink disease is potentially important on cacao in Ghana, and this study provides a foundation for further research on the disease.
\end{abstract}

Keywords: Erythricium salmonicolor; Pink disease; Symptoms; Theobroma cacao

\section{Introduction}

The worldwide threat to cocoa production from the major cacao pests and diseases continue to overshadow other problems of local or sporadic importance. Since the introduction of cacao (Theobroma cacao, L.) into Ghana in 1879 , the main fungal disease limiting production has been Phytophthora pod rot. Pink disease caused by Erythricium salmonicolor (Berk. \& Broome) Burdsall (syn. Corticium salmonicolor Berk. \& Broome), (syn. Phanerochaete samonicolor Berk. \& Broome, Jülich) has been known on cacao for many years [1], but has only been studied in detail as a pathogen of rubber [2]) and Eucalyptus spp. [3]. The disease had earlier been described in Ceylon in 1873 [4]. Edgerton [5] made the first report of the occurrence of E. salmonicolor on a fig tree in Louisiana in the United States. The pathogen is not only a commonly distributed fungus, but it is also virtually omnivorous, having been found on many plant species and over 141 genera [6]. The host plants of economic importance include rubber, tea, coffee, cocoa, grapefruit, orange, nutmeg, mango, apple, coca and kola. In New Guinea and Malaysia, pink disease is associated with cover crops and shade trees such as pigeon pea (Cajanus cajan) and Crotalaria, Tephrosia, Leucaena and Gliricidia [6-9].

Erythricium salmonicolor, Berk. \& Broome was first reported in Ghana by Wharton [10]. In 1999, the disease was found to be severely affecting different varieties of cacao on experimental plots at Bunso in the Eastern Region of Ghana [11]. During routine surveys to monitor the spread and distribution of the black pod pathogen, Phythophthora megakarya on cacao in Ghana, pink disease was found on cacao farms at Ahafo Ano North and Atwima Nwabiagya districts in the Ashanti Region; Asutifi, Dormaa and Tano North districts in the Brong Ahafo Region; Atiwa, Birim South, East Akim, Fanteakwa and Kwaebibirim districts in the Eastern Region and recently at Asankragua and Sefwi Wiawso in the Western Region [12].

Pink disease can cause significant losses, ranging from the loss of individual branches to death of the whole tree if the main stem or several branches are affected. The pathogen usually causes girdling cankers which disrupts the physiological processes leading to defoliation and death of the distal parts of the tree. Disease incidence of about $80 \%$ or more in cacao was reported in Western Samoa [13]) and the disease was also reported to severely affect plants of about 2-6 years old, causing death of the whole tree [2,14]. In Ghana, yield losses due to the disease on experimental plots at Bunso in the Eastern region ranged between 60 and $100 \%$ [11]). The upsurge of the disease in the Western Region of Ghana, a region which accounts for over $40 \%$ of the national cocoa output and earlier reports of sporadic occurrences in the other cacao growing regions [12] is of great concern to the cocoa industry. It is apparent that very soon production levels in these areas will decline as a result of the pink disease unless there is rapid intervention.

In spite of reports of the disease in the country over the years, farmers in outbreak areas have little knowledge of the disease and are unable to identify the disease. The effects of the disease on yield and evaluation of management methods have also not been assessed in detail. This study was aimed at assessing the incidence and severity of pink disease in selected districts of the Western Region and the effect of the disease on yield of cacao. It was also to confirm the identity of the pink disease pathogen, describe symptoms on cacao in Ghana to

*Corresponding author: Andrews Y Akrofi, Cocoa Research Institute of Ghana, P. O. Box 8, Akim Tafo, Ghana, Tel: 233 244715009; Fax: 233 342021157; E-mail andrewsakrofi@yahoo.com

Received: December 24, 2013; Accepted January 09, 2013; Published January 14,2014

Citation: Akrofi AY, Amoako-Atta I, Assuah M, Kumi-Asare E (2014) Pink Disease Caused by Erythricium salmonicolor (Berk. \& Broome) Burdsall: An Epidemiological Assessment of its Potential Effect on Cocoa Production in Ghana. J Plant Pathol Microb 5: 215. doi:10.4172/2157-7471.1000215

Copyright: (C) 2014 Akrofi AY, et al. This is an open-access article distributed under the terms of the Creative Commons Attribution License, which permits unrestricted use, distribution, and reproduction in any medium, provided the original author and source are credited. 
Citation: Akrofi AY, Amoako-Atta I, Assuah M, Kumi-Asare E (2014) Pink Disease Caused by Erythricium salmonicolor (Berk. \& Broome) Burdsall: An Epidemiological Assessment of its Potential Effect on Cocoa Production in Ghana. J Plant Pathol Microb 5: 215. doi:10.4172/21577471.1000215

facilitate easy identification by farmers and extension personnel, and also evaluate selected fungicides for the management of the disease.

\section{Materials and Methods}

\section{Disease survey}

From September to December, 2013, 128 cacao farmers' farms in 11 administrative districts in the Western region of Ghana (Figure 1) were surveyed for incidence and severity of pink disease. The bulk of Ghana's cocoa is produced in the Western region. The number of farms surveyed per district ranged between 5 and 25. On each farm, disease incidence was estimated through visual inspection of 200 cacao trees along a diagonal transect. Infected cacao trees were tagged and symptoms on the various parts of the tree described. Extension agents, farm owners or caretakers of infected farms were interviewed to estimate the year they first observed the disease. Shade trees on the farms were also observed for pink disease symptoms.

Each infected cacao plant on each farm was assessed for disease severity. Disease severities were categorized as follows:

a. mildly infected - trees with 1-25\% of branches infected

b. moderately infected-trees with $26-50 \%$ infection

c. severely infected-trees with $51-75 \%$ infection

d. very severely infected-trees with $76-100 \%$ infection.

\section{Isolation}

Isolations were made directly from cobwebby and pink pustular growth forms on the surface of infected branches. A $4 \times 4 \mathrm{~mm}^{2}$ portion of advancing margins of lesions from the two growth forms was surface sterilized in $70 \%$ alcohol for $3 \mathrm{~min}$. and washed in three changes of sterile distilled water. The portion was transferred to a selective medium for the isolation of basidiomycetous fungi containing dichloran, benomyl and streptomycin [15] and incubated at $28^{\circ} \mathrm{C}$ for 8 days. The colony morphologies of the pathogen on the media and microscopic observation of the fruiting bodies were described.

\section{Effect of pink disease on yield}

A farmer's farm at Akim Asamama in the Atiwa district ( $6^{\circ} 18^{\prime} 50.4^{\prime}$ $\mathrm{N}, 0^{\circ} 35^{\prime} 24^{\prime} \mathrm{W}$ ) of the Eastern Region of Ghana with high incidence of pink disease was selected and used to assess the effect of the disease on cocoa pod production. The farm features undulating terrain and planted with mixed hybrid cocoa interspersed with permanent shade trees. The level of infection on each cacao tree on the farm was assessed and the trees were categorised into severity groups as above. Twenty trees per severity group were randomly selected and twenty healthy trees served as control. Pods in the canopy and on the trunk of trees in each severity group were counted separately at monthly intervals, and to avoid possible double counting, counted pods were tagged.

\section{Pathogenicity testing}

Two isolates of E. salmonicolor Berke. \& Broome, one from Akim Asamama in the Atiwa district $\left(6^{\circ} 18^{\prime} 50.4^{\prime} \mathrm{N}, 0^{\circ} 35^{\prime} 24^{\prime} \mathrm{W}\right)$, Eastern region and the other from Elubo in the Jumoro district $\left(5^{\circ} 17^{\prime} 0^{\prime \prime} \mathrm{N}, 2^{\circ}\right.$ $46^{\prime} 0^{\prime \prime} \mathrm{W}$ ) in the Western region were tested for pathogenicity on eightmonth old hybrid cacao seedlings grown in black polybags $(12.5 \times 15$ $\mathrm{cm}$ ) containing heat-sterilized top soil. The inoculum was $5 \mathrm{~cm}$ long cocoa twig artificially infected with $E$. salmonicolor. The twigs were cut from 3-week old chupons from a hybrid cacao tree and dipped into one-cm deep malt extract agar media centrally inoculated with single strand Akim Asamama and Elubo isolate of E. salmonicolor Berk. \& Broome grown on water agar. The twigs were arranged $2 \mathrm{~cm}$ from the inoculum and incubated at $28^{\circ} \mathrm{C}$ until each twig was entirely covered by the fungal mycelia. The infected twig was aseptically removed and then attached to the seedling by fastening with a transparent polythene sheet at $15 \mathrm{~cm}$ from the soil surface. Uninoculated seedlings served as control. There were 15 plants for each treatment. The treatments were left under mature cacao trees, which provided shade and a humid environment for infection. The seedlings were watered every other day and observed for lesion establishment and development.

\section{Effect of fungicides on pink lesion development}

Three fungicide formulations, Kocide 2000DF (53.8\% Copper [II] hydroxide), Fungikill 50WP (35\% copper [II] hydroxide and 15\% metalaxyl) and Carlit (31.1\% fosetyl aluminium +31.1 metalaxyl $+2.2 \%$ benalaxyl), which proved promising from laboratory assay, were tested at two- and four-weekly intervals on progress of pink disease lesion growth on naturally infected cocoa trees on a farmer's farm at Akim Asamama. The farm was selected based on its proximity to Akim Tafo and its accessibility to facilitate continuous monitoring and also to demonstrate to farmers in the locality, management option available to them. All Cocoa Research Institute of Ghana's recommended cultural practices including pruning were carried out on the farm. Fungicides were sprayed from September to December, 2012, a period when pink disease symptoms were apparent in the field. Kocide 2000DF, Fungikill 50WP and Carlit at $100 \mathrm{~g}, 75 \mathrm{~g}$ and $50 \mathrm{~g}$ in $15 \mathrm{~L}$ of water respectively were sprayed at two- and four-weekly intervals with pneumatic knapsack sprayer. Five replicate trees were maintained for each treatment and five untreated trees served as control. Infected branches were assessed monthly and the lesion growth measured.

\section{Statistical analyses}

Regression analyses were used to estimate the relationship between observed and expected reduction in cocoa yield due to pink disease in the cacao canopy and on the trunk.

\section{Results}

\section{Incidence and severity of pink disease}

Pink disease was identified on 46 out of the 128 cacao farms and in seven out of the 11 districts surveyed. A total of 25,600 cacao trees were inspected and $393(1.6 \%)$ were infected by pink disease. In the infected districts, pink disease incidence ranged from $0.5 \%$ in the Wassa Amenfi West (Amw) district to $4.9 \%$ in the Juaboso (Jua) district (Table 1). The highest number of infected trees (115) was found in the Sefwi Wiawso (Sfw) district. The disease was not found in Aowin (Aow), Mpohor/Wassa East (Mpe), Tarkwa/Prestea/Huni Valley (Tph) and Akontombra (Ako) districts indicating that pink disease is more prevalent in the eastern part of the Western region (Figure 1). On infected farms, the disease was not contiguous but more common in humid areas and in closely spaced plantings with interlocking branches. The earliest date the disease was found in the region was in 2006 during a survey to ascertain the distribution of Phytophthora megakarya on cocoa farms in Ghana. All severity groups were recorded in the Wassa Amenfi East and Sefwi Wiawso districts. However, majority of the diseased trees were mildly infected (62.4\%), and only $2 \%$ were severely infected and apparently killed (Table 2).

\section{Symptoms in the field}

Disease symptom was characterized initially by dieback of infected branches with the brown dead leaves within the otherwise green canopy 
Citation: Akrofi AY, Amoako-Atta I, Assuah M, Kumi-Asare E (2014) Pink Disease Caused by Erythricium salmonicolor (Berk. \& Broome) Burdsall: An Epidemiological Assessment of its Potential Effect on Cocoa Production in Ghana. J Plant Pathol Microb 5: 215. doi:10.4172/21577471.1000215

\begin{tabular}{|l|l|l|l|l|l|}
\hline District & \multicolumn{3}{l}{ Number of } \\
\hline & $\begin{array}{l}\text { Farms } \\
\text { surveyed }\end{array}$ & $\begin{array}{l}\text { Farms } \\
\text { infected }\end{array}$ & $\begin{array}{l}\text { Trees } \\
\text { inspected }\end{array}$ & $\begin{array}{l}\text { Trees } \\
\text { infected }\end{array}$ & $\begin{array}{l}\text { Year of } \text { 1 }^{\text {st }} \\
\text { observation }^{\text {b }}\end{array}$ \\
\hline $\begin{array}{l}\text { Wassa Amenfi East } \\
\text { (Ae) }\end{array}$ & 15 & 10 & 3,000 & $92(3.1)$ & 2008 \\
\hline $\begin{array}{l}\text { Wassa Amenfi West } \\
\text { (Amw) }\end{array}$ & 25 & 7 & 5,000 & $24(0.5)$ & 2006 \\
\hline $\begin{array}{l}\text { Wass Amenfi Central } \\
\text { (Amc) }\end{array}$ & 8 & 6 & 1,600 & $15(0.9)$ & 2011 \\
\hline Aowin (Aow) & 6 & 0 & 1,200 & $0(0.0)$ & NA \\
\hline Juaboso (Jua) & 10 & 6 & 2,000 & $98(4.9)$ & 2010 \\
\hline $\begin{array}{l}\text { Mpohor/Wassa East } \\
\text { (Mpe) }\end{array}$ & 13 & 0 & 2,600 & $0(0.0)$ & NA \\
\hline Bia (Bia) & 9 & 3 & 1,800 & $15(0.8)$ & 2011 \\
\hline Sefwi Wiawso (Sew) & 14 & 11 & 2,800 & $115(4.1)$ & 2006 \\
\hline Akontombra(Ako) & 5 & 0 & 1,000 & $0(0.0)$ & NA \\
\hline $\begin{array}{l}\text { Tarkwa/Prestea/Huni } \\
\text { Valley (Tph) }\end{array}$ & 11 & 0 & 2,200 & $0(0.0)$ & NA \\
\hline $\begin{array}{l}\text { S. Bekwai/Bibiani/ } \\
\text { Anwiaso (Sba) }\end{array}$ & 12 & 3 & 2400 & $34(4.3)$ & 2011 \\
\hline Total & 128 & $\mathbf{4 6}$ & $\mathbf{2 5 , 6 0 0}$ & $\mathbf{3 9 3}$ & \\
\hline
\end{tabular}

aPercent infection in brackets; bnot available

Table 1: Pink disease assessment in eleven districts in Western Region of Ghana

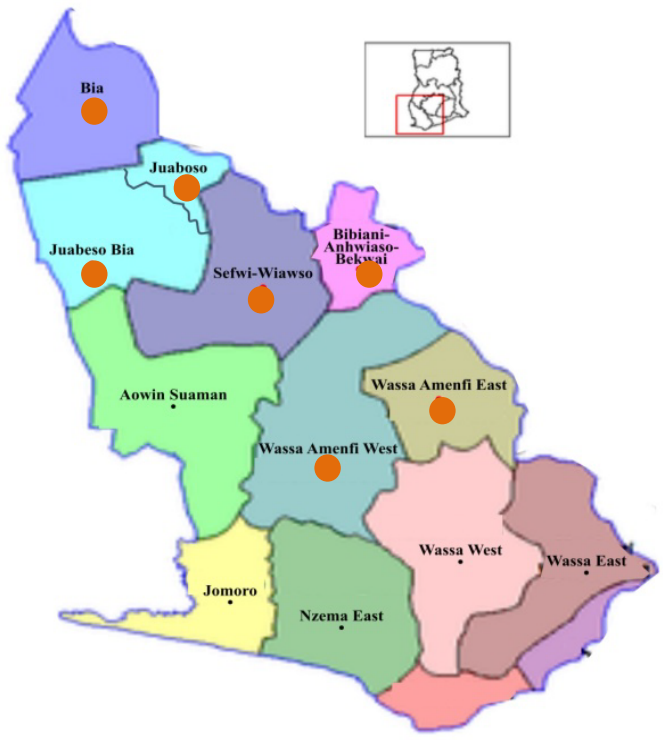

Figure 1: Map of Western Region of Ghana showing districts infected with pink disease (marked ) from the 2012/13 survey.

\begin{tabular}{|l|l|l|l|l|l|l|l|l|}
\hline \multirow{2}{*}{$\begin{array}{l}\text { Severity } \\
\text { class }\end{array}$} & \multicolumn{9}{|c|}{ District* } & \% Severity \\
\cline { 2 - 9 } & Ame & Amw & Amc & Jua & Bia & Sew & Sba & \\
\hline Mild & 62 & 14 & 8 & 68 & 4 & 61 & 28 & 62.4 \\
\hline Moderate & 25 & 9 & 6 & 27 & 11 & 47 & 6 & 33.3 \\
\hline Severe & 3 & 1 & 1 & 3 & 0 & 1 & 0 & 2.3 \\
\hline Very severe & 2 & 0 & 0 & 0 & 0 & 6 & 0 & 2.0 \\
\hline $\begin{array}{l}\text { Total trees } \\
\text { infected }\end{array}$ & 92 & 24 & 15 & 98 & 15 & 115 & 34 & 100 \\
\hline
\end{tabular}

*See text for full names of districts

Table 2: Distribution of severity rating of pink disease in affected districts in Western Region of Ghana from the September-December, 2013 survey.

of the trees. The dead leaves remained attached to the declining trees for several weeks when observed from a distance. The disease appear as coating of brown to pink incrustation of hyphae (fruiting bodies), yellowing and browning of leaves and complete defoliation on severely affected branches and twigs. A closer observation of an infected branch revealed a coating of drab paint on the branch. Irrespective of age, affected branches manifest the following symptoms (Figure 2, top panel); typical pinkish to orange coloration (Figure $2 \mathrm{a}$ ) and dieback symptoms. Desiccated flowers (Figure $2 \mathrm{~b}$ ) and mummified fruits (Figure 2c) remain attached to declining trees for several weeks. The affected barks of such declining trees were usually dry with several longitudinal cracks (Figure 2d). Although tree dieback occurred throughout the year, symptoms were more prevalent during the dry season, especially for trees on farms with little or no shade.

Four distinct growth forms of pink disease were identified on the bark of infected cacao trees in Ghana (Figure 2, middle panel). These were cobwebby, pink to salmon-colored incrustation, creamy pustules and orange fruiting bodies. The cobwebby stage appeared as a layer of light white to pink-coloured vegetative mycelia on the surface of the bark (Figure 2e) and was followed by the formation of pink to salmoncolored pustules on any part of the infected branch (Figure 2f). The third growth stage consisted of creamy pustules which are more conspicuous on the underside of the branch (Figure $2 \mathrm{~g}$ ) which developed into orange fruiting bodies (Figure $2 \mathrm{~h}$ ) on dying infected stems, branches and twigs. All four growth forms may be found together on the diseased bark at the same time but the most conspicuous and distinctive are the salmon-pink encrustations formed by hyphal fruiting bodies earlier described on branches and stems of the tree, causing twig and branch injuries, stem canker, and eventually host plant death [16].

\section{Morphology on agar media}

On the selective medium, colonies from cobwebby growth form appeared cottony-white with thread-like mycelia at the advancing margins (Figure 2i) but turned creamy with age (Figure 2j). In contrast, colonies from pink pustules were initially pink (Figure $2 \mathrm{k}$ ) but turned creamy (Figure 2l) within one week. None of the isolates from the different growth stages produced spores in culture. However, microscopic examination of naturally infected branches showed the pustular forms producing hyaline non-septate hyphae (Figure $2 \mathrm{~m}$ ) and masses of irregularly shaped hyaline, unicellular, ellipsoid spores, 10$24 \mu \times 8-12 \mu$ (Figure 2n). All the isolates were identified as Erythricium salmonicolor (syn. Corticium salmonicolor, Berk. and Broome) based on symptoms in the field and microscopic examination of the fruiting bodies.

\section{Pathogenicity test}

Both Akim Asamama and Elubo isolate of E. salmonicolor, Berk. and Broome established on the inoculated seedlings. However, while mycelial growth rate of Asamama isolate was faster, Elubo isolate proved to be more virulent. After 6 months, $90 \%$ of the inoculated test plants became irreversibly desiccated reproducing symptoms similar to that observed on branches in the field. In contrast, the uninoculated control plants remained healthy. Erythricium salmonicolor, Berk. and Broome was re-isolated from all infected plants.

\section{Effect of pink disease on cocoa pod production}

Pink disease infection reduced cocoa pod production significantly $(\mathrm{p}<0.05)$. More pods were lost in the canopy $(8.6$ pods/tree) compared to the trunk (6.7 pods/tree). As severity of the disease increased, pod numbers in the canopy reduced. The mean number of pods per tree in the canopy declined from 41 in the healthy to 26 in the mildly infected, 22 in moderately infected, 8 in severely infected and 7 in very severely 
Citation: Akrofi AY, Amoako-Atta I, Assuah M, Kumi-Asare E (2014) Pink Disease Caused by Erythricium salmonicolor (Berk. \& Broome) Burdsall: An Epidemiological Assessment of its Potential Effect on Cocoa Production in Ghana. J Plant Pathol Microb 5: 215. doi:10.4172/21577471.1000215



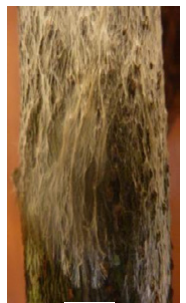

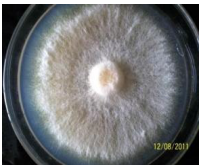

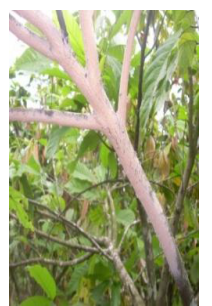

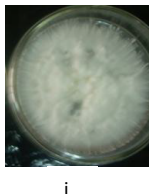

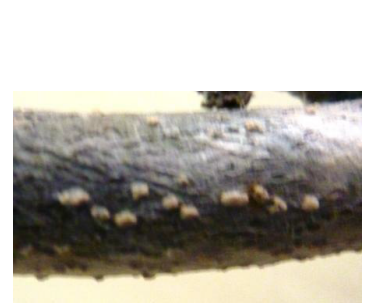

g

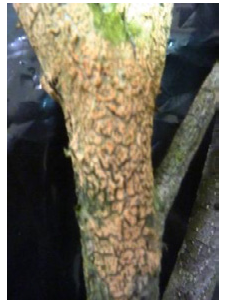

h

Figure 2: Symptoms of pink disease (top panel) showing pinkish colouration of infected branches (a), desiccated flowers (b), mummified pod (c) and severe cracks on bark of declining infected cacao tree (d); development stages of E. salmonicolor (Berk. \& Broome) on cacao (middle panel) indicating vegetative mycelia mat (e), pink to salmon-colored pustules (f), creamy pustules ( $\mathrm{g}$ ) and orange pustules on a branch $(\mathrm{h})$; and colony morphology and microscopic examination of E. salmonicolor (Berk. \& Broome) isolate (lower panel) showing colony morphology 7 dai (i) and 28 dai (j) from cobweb growth stage and 3 dai (k) and 7 dai (I) from pink-coloured pustules, incubated at $28^{\circ} \mathrm{C} \pm 2^{\circ} \mathrm{C}$ on selective medium for basidiomycetes and hyaline non-septate hyphae (m) and irregularly shaped hyaline, unicellular, ellipsoid spores $(n)$ from pustules on naturally infected branches.

infected trees (Figure 3). Similarly, an increasing trend of pod reduction with increase in pink disease severity was observed on the trunk.

\section{Disease management}

The effects of different fungicides and their interval of application on pink disease progress on naturally infected cacao trees at Akim Asamama are presented in Figure 4. Pink disease was not controlled with Fungikill 50WP applied at two- and four-weekly intervals though lesion growth at 2-weekly interval application was slower than on the 4 -weekly interval. Carlit and Kocide 2000DF at two- and four-weekly intervals proved effective against the disease in the initial stages of application. However, eight-weeks after application, lesion re-growth was recorded on Carlit sprayed at four-weekly interval and after 20 weeks, the lesion length had reached $5 \mathrm{~cm}$. Similar re-growth was observed on Carlit sprayed at two-weekly interval but lesion re-growth was delayed until 12 weeks and at 20 weeks, the lesion had unexpectedly attained a length of $9 \mathrm{~cm}$. There was no growth of pink disease lesion on Kocide 2000DF treated trees.

\section{Discussion}

Other than preliminary reports [10,11], this study represents the first detailed report of pink disease on cacao on farmers' farms in the Western region of Ghana. Pink disease was earlier reported in the Western region on cacao farms at Asankragua in the Amenfi West district and later at Sefwi Wiawso during a survey to establish the distribution of Phythophthora species in the country. The current study shows that the disease is spreading widely in the eastern part of the region, and it is currently confirmed in five more districts, Amenfi East, Amenfi Central, Juaboso, Bia and Sefwi Bekwai/Bibiani/ Anwiaso, and a total of 17 cocoa growing districts in the country. The distribution of the disease on farms and in the districts is not contiguous, and thus, the disease was not found in some districts in the region and on any of the shade trees on the cocoa farms surveyed. This confirms the earlier finding by Opoku et al. [11] in which none of the shade trees on the experimental plots surveyed were infected. However, E. salmonicolor, Berk. and Broome is known to be a common widespread pathogen of tropical woody trees, having been found on over 141 genera of plants causing shoot blight and dieback of trees and shrubs [6]. All the infections on the farms surveyed were natural and the source(s) and amount of primary inoculum were unknown. These factors could be variable in the districts and farms surveyed and could account for the absence of the disease on some farms and on trees other than cacao. The absence of the disease on some farms and on some cacao and forest trees could also have been due to escape rather than their inherent resistance. Further surveys will therefore be required to confirm this present finding. The districts where the disease has been confirmed have high annual rainfall averages (above $1000 \mathrm{~mm}$ ). This agrees with findings that pink disease becomes increasingly prevalent and damaging in areas of high rainfall [17]. Basidiospore germination in E. salmonicolor has also been shown to be efficient at $100 \%$ relative humidity [18]. This correlation suggests that the disease can easily spread in the cacao growing regions and will help to focus future 
Citation: Akrofi AY, Amoako-Atta I, Assuah M, Kumi-Asare E (2014) Pink Disease Caused by Erythricium salmonicolor (Berk. \& Broome) Burdsall: An Epidemiological Assessment of its Potential Effect on Cocoa Production in Ghana. J Plant Pathol Microb 5: 215. doi:10.4172/21577471.1000215

$\square$ Canopy $\left(y=-8.55 x+46.4 ; r^{2}=0.93\right)$

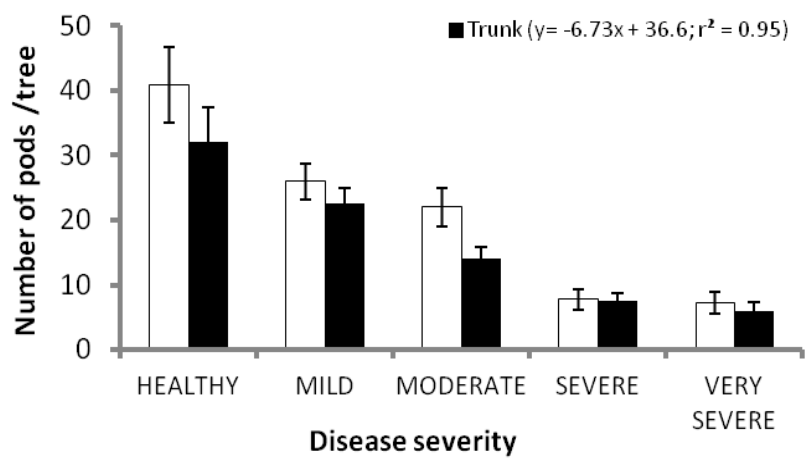

Figure 3: Effect of pink disease on cocoa pod production. Bars represent standard errors.

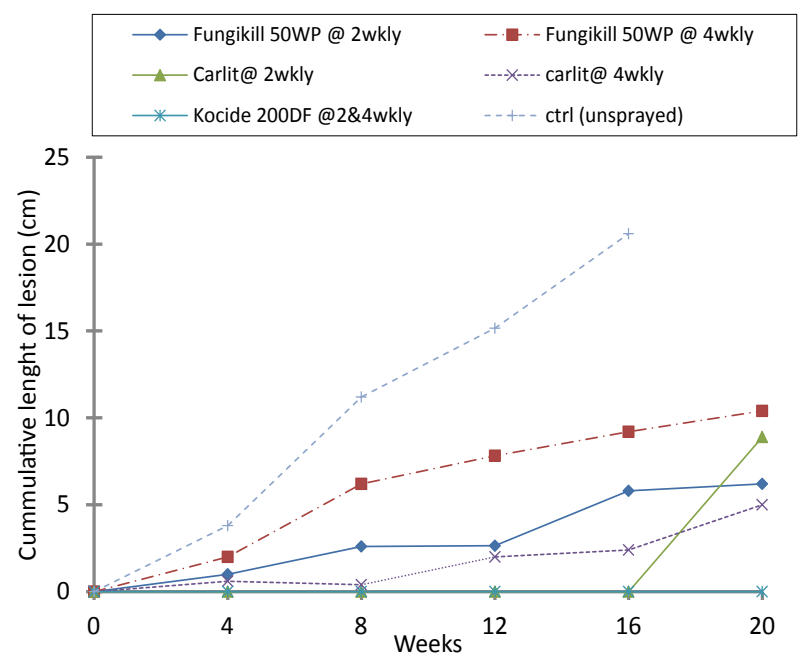

Figure 4: Effects of different fungicides and their intervals of application on pink disease progress on naturally infected cocoa trees at Akim Asamama E/R.

surveys for pink disease in Ghana because most cocoa growing areas in the country have annual rainfall above $1000 \mathrm{~mm}$ per annum.

Most farmers were not familiar with the disease and regarded it as 'sun-burns'. A description of the symptoms on cacao and various growth forms will facilitate easy identification of the disease by farmers and extension personnel. The study showed that even though there are four different growth forms, all these forms could be found together on a diseased branch. To facilitate identification of the disease by farmers and extension personnel, a fact sheet highlighting and describing the symptoms with pictures is required. Education on the disease also needs to be intensified.

From the study, pink disease was found to significantly reduce cocoa yield. The effect of the disease was also more pronounced in the canopy than on the trunk. Infections were largely confined to the branches, although the trunks of a few stands below the first jorquette were in the advanced stage of infection. Although all the affected trees survived the attack, most of their branches died from the infections. The disease is known to result in girdling cankers which disrupts the physiological processes leading to defoliation and death of the distal parts of the tree. This ultimately results in reduction in photosynthate production and consequently, reduction in cocoa yield. The study showed that flowers as well as pods could be infected. It is therefore not surprising that pod numbers in both the canopy and on the trunk decreased as the severity of the disease increased.

Apart from ensuring good drainage, shade reduction and removal of susceptible forest and shade trees to control pink disease $[9,19]$ the disease can also be controlled by frequent pruning and burning of infected parts, supplemented with fungicide treatment. Fungicides reported to show activity against E. salmonicolor, Berk. and Broome include copper formulations such as Bordeaux mixture, copper oxychloride, copper carbonate [20-23], tridemorph paints in an ammoniated latex base [24]); triadimefon granules [25]; chlorothalonil paints in a latex/bitumen base [8] and fenpropimorph [26]. In the current study, Kocide 2000DF, a copper-based only fungicide was the most effective in controlling the disease. Thus cultural control, including pruning of infected branches supplemented with monthly spraying of Kocide 2000DF fungicide holds promise for effective control of pink disease in Ghana.

\section{Conclusions}

Although pink disease is known to occur in Ghana, its spread in the Western Region, the major cocoa producing region in the country is being reported for the first time. Also, for the first time in Ghana, an elaborate description of symptoms of the disease has been documented and the effect of the disease on cocoa yield has been demonstrated. A method for managing the disease has also been demonstrated and thus farmers have assurance that pink disease, hitherto, suspected to be a "strange" disease on cacao can be managed.

\section{Acknowledgements}

Our thanks go to Dr. G. Akumfi-Ameyaw for his suggestions in the preparation of this paper. The assistance of the technical staff of Plant Pathology Division of CRIG in the disease assessment is also gratefully acknowledged. This paper CRIG/06/2013/037/ is published with the permission of the Executive Director, Cocoa Research Institute of Ghana, Akim Tafo.

\section{References}

1. Stockdale FA (1909) Fungus diseases of cacao and sanitation of cacao orchards. West Indian Bulletin 9:166.

2. Holliday $P$ (1980) Fungus diseases of Tropical crops. Cambridge University Press: London.

3. Old KM, Davidson EM (2000) Canker diseases of Eucalyptus. In Diseases and Pathogens of Eucalypts. Keane PJ, Kile GA, Podger FD and Brown BN (eds) CSIRO Publishing, Collingwood, Australia.

4. Berkeley MJ, Broome CE (1875) Enumeration of the fungi of Ceylon. J Linn Soc 14: 29-64.

5. Edgerton CW (1911) Two new fig diseases. Phytopathology 1: 12-17.

6. Smith ESC (1985) A review of the relationship between shade types and cocoa pest and disease problems in Papua New Guinea. Papua New Guinea Journal of Agriculture, Forest and Fisheries 33: 78-88.

7. Green ECD (1938) Cocoa cultivation and its application to the Mandated Territory of New Guinea. New Guinea Agricultura Gazette 6: 1-63.

8. Anon (1985) Crop Protection. Annual Report 1984, Rubber Research Institute of Malaysia, 27-28.

9. Wood GAR, Lass RA (1985) Cocoa. ( $4^{\text {th }}$ edn), Tropical Agricultural Series Longman, London.

10. Wharton AL (1962) Black pod and minor diseases. In: Agriculture and Land Use in Ghana. Brian Wills J (ed). Oxford University Press, London 333-342.

11. Opoku IY, Akrofi AY, Osei-Bonsu K, Acheampong K (2001) An outbreak of pink disease in Ghana. Proc. of the $13^{\text {th }}$ Int. Cocoa Res. Conf, Kota Kinabalu, Sabah, Malaysia, 761-767. 
Citation: Akrofi AY, Amoako-Atta I, Assuah M, Kumi-Asare E (2014) Pink Disease Caused by Erythricium salmonicolor (Berk. \& Broome) Burdsall: An Epidemiological Assessment of its Potential Effect on Cocoa Production in Ghana. J Plant Pathol Microb 5: 215. doi:10.4172/21577471.1000215

12. Akrofi AY, Opoku, IY, Assuah MK, Sarfo JE (2008) Survey of Phytophthora isolates in Ghana. In: Rep. Cocoa Res Inst Ghana, 123.

13. Schneider-Christians J, Fliege F, Schlosser E, Tamani R (1983) Pink disease of cocoa caused by Corticium salmonicolor in Western Samoa. Survey of the occurrence of the disease. Alafua Agricultural Bulletin 8: 9-19.

14. Brown JF, Friend D (1973) Diseases of cocoa in the British Solomon Islands Protectorate South Pacific Commission. Technical Paper 166.

15. Worall JJ (1991) Media for selective isolation of hymenomycetes. Mycologia 83: 296-302.

16. Sharples A (1936) Diseases and pests of the rubber tree. Printed by Macillan \& Co. Ltd, London 267-277.

17. Seth SK, Bakshi BK, Reddy MAR, Sujan S (1978) Pink disease of Eucalyptus in India. Eur J for Pathol 8: 200-216.

18. Schneider-Christians J, Fliege F, Schlosser E (1986) On the release, survival and importance of basidiospores of Corticium salmonicolor, the pathogen causing pink disease. J Plant Dis Prot 93: 397-403.

19. Hill DS, Waller JM (1982) Pests and diseases of Tropical crops. Volume 2 Field Handbook. Harlow, Essex, UK: Longman Group UK Limited 432.
20. Ram A, Bastos STG, Figueiredo JM de (1982) Chemical control of Corticium salmonicolor, causal agent of pink disease of cocoa. Revista Theobroma 12 241-247.

21. Kueh TK (1986) Cocoa diseases. Annual Report of the Research Branch, Department of Agriculture, Sarawak, 1984. Kuching, Sarawak: Minist. Agric Community Development 83-85.

22. Thankamma $L$ (1989) In vivo evaluation of fungicides and antagonistic fungus in pink disease management of Eucalyptus when applied as brush on formulation, Pesticides 23: 39-41.

23. Thankamma L, Nair JMN, Deo AD, Kumar D (1986) Prophylactic brush-on application of Emulsicop for pink disease management in Eucalyptus. Indian Forester 112: 1016-1018.

24. Edathil TT, Jacob CK (1983) Control of pink disease of Hevea using tridemorph in ammoniated latex. Pesticides 17: 25-26.

25. Villarraga ALA (1987) Dosage and frequency of application of granulated systemic fungicides to control coffee rust in Colombia. ASCOLFI-Informa 13 49-50.

26. Luz EDMN, de Figueiredo JM (1982) Sensitivity of Corticium salmonicolor to fungicides in vitro. Theobroma Revista 12: 249-255. 